\title{
GERMINATION OF CREOLE MAIZE AND FAVA BEAN SEEDS UNDER SALT STRESS ${ }^{1}$
}

\author{
CARLA DE SOUZA ALMEIDA²*, HUGO ROLDI GUARIZ³ ${ }^{2}$, MARÍLIA ALVES BRITO PINTO ${ }^{4}$, MARINEIDE \\ FERREIRA DE ALMEIDA ${ }^{3}$
}

\begin{abstract}
Salt stress negatively affects plant development, mainly in arid and semiarid regions, promoting changes in their physiology and productivity. The objective of this study was to evaluate the germinative potential of creole maize (Zea mays L.) and fava bean (Phaseolus lunatus L.) seeds under different salt stress conditions. The seeds were collected in rural areas of the municipalities of Guanambi, Candiba, and Brumado, which are within the Serra Geral region in the state of Bahia, Brazil. A completely randomized experimental design was used; the treatments consisted of three salts $\left(\mathrm{CaCl}_{2}, \mathrm{MgCl}_{2}\right.$, and $\left.\mathrm{NaCl}\right)$ and four salinity levels (osmotic potentials of $-0.3,-0.9$, and $-1.2 \mathrm{MPa}$ ). Seed physical analyses included moisture and purity, and physiological analyses included germination percentage, germination speed index, average germination time, and relative germination frequency. The storage of creole maize and fava bean seeds in plastic bottles and under adequate humidity ensures that seeds will have moisture content and physical purity within ideal values. Salt stresses induced by $\mathrm{NaCl}$ and $\mathrm{CaCl}_{2}$ salts at osmotic potentials of -0.3 to $-1.2 \mathrm{MPa}$ hinder the creole maize and fava bean seed germination, and their germination are null for both salts at osmotic potentials lower than $0.3 \mathrm{MPa}$. The creole maize and fava bean seeds show germination of $70 \%$ under salt stress induced by $\mathrm{MgCl}_{2}$ at osmotic potential of $-0.3 \mathrm{MPa}$, making the germination of both species viable.
\end{abstract}

Keywords: Zea mays. Phaseolus lunatus. Salinity. Traditional varieties.

\section{ESTRESSE SALINO NA GERMINAÇÃO DE SEMENTES CRIOULAS DE MILHO E FEIJÃO-FAVA}

RESUMO - O estresse salino afeta negativamente o desenvolvimento de plantas, principalmente em regiões áridas e semiáridas, promovendo alterações em sua fisiologia e produtividade. Objetivou-se avaliar o potencial germinativo de sementes crioulas de milho (Zea mays L.) e feijão-fava (Phaseolus lunatus L.) em condições de estresse salino, com diferentes potenciais e sais. As sementes foram coletadas em áreas rurais, nos municípios de Guanambi, Candiba e Brumado, região do Brasil que corresponde a Serra Geral da Bahia. O delineamento experimental foi inteiramente casualizado e os tratamentos constituíram-se por três sais $\mathrm{CaCl}_{2}, \mathrm{MgCl}_{2}$ e $\mathrm{NaCl}_{\text {, }}$ além de quatro potenciais de salinidade $0 ;-0,3 ;-0,9$ e -1,2 $\mathrm{MPa}$. As análises físicas das sementes incluíram umidade e pureza física, enquanto que as análises fisiológicas foram: porcentagem de germinação, índice de velocidade de germinação, tempo médio de germinação e frequência relativa de germinação. $\mathrm{O}$ armazenamento das sementes crioulas de feijão-fava e milho feito em garrafas pet com volume totalmente preenchido somado à colheita com a umidade adequada, garante que as sementes apresentem grau de umidade e pureza física dentro dos valores considerados ideias. O estresse salino induzido pelos sais $\mathrm{NaCl}$ e $\mathrm{CaCl}_{2}$, com potenciais osmóticos entre - 0,3 e -1,2 MPa é prejudicial à germinação de sementes crioulas de feijão-fava e milho, e em potenciais menores que $-0,3 \mathrm{MPa}$ a germinação é nula para ambos os sais. As sementes crioulas de milho e feijão-fava apresentam germinação de $70 \%$ na solução de $\mathrm{MgCl}_{2}$ no potencial osmótico de $-0,3 \mathrm{MPa}$, nesta condição a germinação de ambas às espécies é viável.

Palavras-chave: Zea mays. Phaseolus lunatus. Salinidade. Variedades tradicionais.

\footnotetext{
${ }^{*}$ Corresponding author

${ }^{1}$ Received for publication in 10/28/2019; accepted in 03/15/2020.

Paper extracted from the undergraduate final project of the first author.

${ }^{2}$ Department of Phytotechnics, Universidade Estadual do Sudoeste da Bahia, Vitória da Conquista, BA, Brazil; carla.bdo@hotmail.com ORCID: 0000-0003-4382-2955.

${ }^{3}$ Instituto Federal de Educação, Ciência e Tecnologia Baiano, Guanambi, BA, Brazil; hugo.guariz@gmail.com - ORCID: 0000-0003-4343379X, neideferreirars@gmail.com - ORCID: 0000-0002-3289-7022.

${ }^{4}$ Center of Technological Development/Water Resources Engineering, Universidade Federal de Pelotas, Pelotas, RS, Brazil; ma.agro@gmail.com - ORCID: 0000-0002-7771-025X.
} 


\section{INTRODUCTION}

High soil salinity levels are found in arid and semiarid regions due to the low rainfall depths, low bioclimatic activity, low weathering degree and poor drainage of the soil, and use of poor-quality water (HOLANDA et al., 2007). High salinity is an increasing problem in the Semiarid region in the Northeast of Brazil; thus, studies about the crops grown in these regions are important, mainly those tolerant to salt stress (NASCIMENTO et al., 2017).

Creole seeds from different species are commonly found in family farms; these seeds have been maintained for generations and represent the work carried out by ancestors who adapted them to the local conditions (SANTOS et al., 2017). Local seed stocks conserved by family farmers have a precious and incalculable genetic value by maintaining the biodiversity and food security of traditional local populations (SANTOS; CURADO; TAVARES, 2019).

Maize (Zea mays L.) and fava bean (Phaseolus lunatus L.) are among the species grown from creole seeds in the Semiarid region of the state of Bahia, Brazil. Maize is a versatile crop of high nutritional value that can be used indirectly, through animal feed, and directly as human food. Maize is a valuable raw material in the food industry, which is the basis of hundreds of different products, and is also used by cosmetic and pharmaceutical industries (BARAVIERA et al., 2014). Fava bean is a species adapted to the climate and soil of the Brazilian Semiarid region and has great importance in the food and nutritional security of small rural communities (BARREIRO NETO et al., 2015).

Despite the adaptation to salt soils, the germination of creole seeds can be compromised by the soil high salinity. Excess $\mathrm{Na}^{+}$and $\mathrm{Cl}^{-}$ions can reduce protoplasmic intumescence and, consequently, the water content and nutrient translocation favorable to germination (GUIMARÃES et al., 2012).

Some studies have been carried out to assess the adaptation of some species to the salt environments, such as maize (PESSOA NETO et al., 2016; SILVA; GRZYBOWSKI; PANOBIANCO, 2016), black bean (MORAIS et al., 2018), and cowpea (GOMES FILHO et al., 2019; NUNES et al., 2019). However, none of them considered Creole seeds, which are widely used by family farmers in the Semiarid region under high-salinity soil conditions.

In this context, the objective of this study was to evaluate the germinative potential of creole maize and fava bean seeds produced in the state of Bahia under different salt stress conditions.

\section{MATERIAL AND METHODS}

Fava bean (Phaseolus lunatus L.) and maize (Zea mays L.) creole seeds were collected in family farms in the municipalities of Guanambi $\left(14^{\circ} 12^{\prime} 30^{\prime \prime} \mathrm{S} ; 42^{\circ} 44^{\prime} 53^{\prime \prime} \mathrm{W}\right.$ and altitude of $\left.525 \mathrm{~m}\right)$, Candiba $\left(14^{\circ} 24^{\prime} 39^{\prime \prime} \mathrm{S}\right.$; $42^{\circ} 52^{\prime} 02^{\prime \prime} \mathrm{W}$ and altitude of $563 \mathrm{~m})$, and Brumado (14 ${ }^{\circ} 16^{\prime} 28^{\prime \prime} \mathrm{S} ; 41^{\circ} 47^{\prime} 01^{\prime \prime} \mathrm{W}$ and altitude of $457 \mathrm{~m}$ ), which are in the Sertão Produtivo Territory, a region that corresponds to the Serra Geral mountain range in the state of Bahia, Brazil. The region climate is classified as semiarid (BSa), according to the Köppen classification.

The seeds were stored in 1-liter plastic bottles and maintained at room temperature in an airy place without light for three months. Seed physical and physiological analyses were carried out at the Plant Physiology Laboratory of the Federal Institute Baiano, in Guanambi, Bahia, Brazil.

Seed moisture content was determined according to the methodology described in the Rules for Seed Analysis (BRASIL, 2009). Four replications of 50 seeds were dried in an oven at $105 \pm 3{ }^{\circ} \mathrm{C}$ for 24 hours, the results were expressed in percentage. The seed physical purity test was carried out using $200 \mathrm{~g}$ of seeds, which were classified as pure seed, other seeds, and inert material. The result was expressed as percentage of pure seeds.

The physiological quality of seeds under salt stress was determined by germination tests. A completely randomized experimental design was used, consisting of 10 treatments, with 15 replications for the fava bean seeds and 10 replications for the maize seeds. The treatments consisted of nine salt solutions resulting from the combination of 3 osmotic potentials $(0.3,-0.9$, and 1.2 $\mathrm{MPa})$ and three salts $\left(\mathrm{CaCl}_{2}, \mathrm{MgCl}_{2}\right.$, and $\left.\mathrm{NaCl}\right)$, using a control with osmotic potential of $0 \mathrm{MPa}$. Salt solutions were prepared with distilled water according to the Van't Hoff equation described by Coelho et al. (2010).

The seeds were sterilized in sodium hypochlorite $(2 \%)$ for one minute, then sown in plastic trays with equidistant spacing, using sand as substrate. The sand was previously sieved and autoclaved at $100{ }^{\circ} \mathrm{C}$ for 1 hour a day, for two days. Water was supplied daily, preventing the sand to dry and according to need of the seeds.

Germination percentage $(\mathrm{G} \%)$, germination speed index (GSI), average germination time (AGT), and relative germination frequency (RGF) of the seeds were determined. 
$\mathrm{G} \%$ was calculated using the equation $G \%=$ $(N / A) \times 100$, where $N$ is the number of germinated seeds at the end of the test, and $A$ is the total number of seeds sowed; AGT was calculated using the equation $A G T$ (days) $\left.=\left(\sum n i t i\right) / \sum n i\right)$, where $n i$ is the number of germinated seeds within a time interval, and $t i$ is the germination time interval; and RGF was calculated using the equation $R G F(\%)=\left(n i / \sum n i\right)$ $\times 100$, where $n i$ is the number of germinated seeds, according to Labouriau and Valadares (1976).

GSI was determined by daily counts of seeds that showed protrusion of primary root, considering germinated those with length of $2 \mathrm{~mm}$ or more. The counting was carried out until the amount of germinated seeds stabilized. GSI was calculated according to the equation proposed by Maguire (1962): $G S I=(G 1 / N 1)+(G 2 / N 2)+\ldots+(G n / N n)$, where $G$ is the number of normal seedlings in each count, and $N$ is the number of days from sowing at the respective counts.

The effect of salt stress due to the different salts and osmotic potentials on creole maize and fava bean seed germination was evaluated by comparing the nine salt solutions with a control treatment using the Dunnett test $(p<0.05)$. The correlation between osmotic potential and relative germination frequency was evaluated by fitting the data to locally weighted regression models (CLEVELAND; DEVLIN, 1988). The difference between treatments was evaluated by comparing the regressions based on their respective $95 \%$ confidence intervals. The sections with overlapped regressions represented no difference between treatments, and overlaps represented differences between treatments. All analyses were performed using the R software (R CORE TEAM,
2016).

\section{RESULTS AND DISCUSSION}

The average moisture content was analyzed as an initial procedure to evaluate the physical quality of the seeds, and showed $12.9 \%$ for the maize and $11.8 \%$ for the fava bean seeds. According to Sarmento, David, and Barbosa (2015), an ideal moisture content for harvest, storage, and marketing of beans and maize seeds is $11.0 \%$ and $13.0 \%$ moisture. The absence of rainfall, low air relative humidity after physiological maturation and during harvest of the seeds, and the good storage containers (plastic bottles properly filled and sealed) contributed to the good moisture contents found.

The average physical purity was $99.9 \%$ for the maize and $98.8 \%$ for the fava bean seeds. According to Ferreira e Sá (2010), the minimum value required for physical is $95 \%$. It was observed that the cleaning operations carried out by the farmers resulted in proper values of physical purity, ensuring better conditions for further processing, and avoiding storage problems.

The results of the fava bean seed germination (Table 1) showed no germination for the $\mathrm{NaCl}$ and $\mathrm{CaCl}_{2}$ salts, regardless of the osmotic potential. Several factors may be related to these results, such as seed genetic variability, post-harvest treatments, and contamination by microorganisms during sowing, since fungal growth was visually observed on the fava bean seeds in these treatments. Germination was $70 \%$ with magnesium chloride $\left(\mathrm{MgCl}_{2} ;-0.3 \mathrm{MPa}\right)$, not differing from the control.

Table 1. Germination percentage (G\%), germination speed index (GSI), and average germination time (AGT) of creole fava bean seeds as a function of different salts and osmotic potentials.

\begin{tabular}{|c|c|c|c|c|c|c|c|c|c|c|}
\hline \multirow{2}{*}{ Variable } & \multirow{2}{*}{ Control } & \multicolumn{9}{|c|}{ Salts } \\
\hline & & $\begin{array}{c}\mathrm{NaCl} \\
-0.3\end{array}$ & $\begin{array}{c}\mathrm{NaCl} \\
-0.9\end{array}$ & $\begin{array}{c}\mathrm{NaCl} \\
-1.2\end{array}$ & $\begin{array}{c}\mathrm{CaCl}_{2} \\
-0.3\end{array}$ & $\begin{array}{c}\mathrm{CaCl}_{2} \\
-0.9\end{array}$ & $\begin{array}{c}\mathrm{CaCl}_{2} \\
-1.2\end{array}$ & $\begin{array}{c}\mathrm{MgCl}_{2} \\
-0.3\end{array}$ & $\begin{array}{c}\mathrm{MgCl}_{2} \\
-0.9\end{array}$ & $\begin{array}{c}\mathrm{MgCl}_{2} \\
-1.2\end{array}$ \\
\hline G \% & 72.0 & $0.0^{*}$ & $0.0^{*}$ & $0.0^{*}$ & $0.0^{*}$ & $0.0^{*}$ & $0.0^{*}$ & $70.0^{\mathrm{ns}}$ & $6.0^{*}$ & $0.0^{*}$ \\
\hline GSI & 0.9 & $0.0^{*}$ & $0.0^{*}$ & $0.0^{*}$ & $0.0^{*}$ & $0.0^{*}$ & $0.0^{*}$ & $0.6^{*}$ & $0.1^{*}$ & $0.0^{*}$ \\
\hline AGT & 9.4 & $0.0^{*}$ & $0.0^{*}$ & $0.0^{*}$ & $0.0^{*}$ & $0.0^{*}$ & $0.0^{*}$ & $12.3^{*}$ & $1.0^{*}$ & $0.0^{*}$ \\
\hline
\end{tabular}

$* \mathrm{P}<0.05 ;{ }^{\mathrm{ns}} \mathrm{P}>0.05$. 
The creole maize seeds germinated in all salts at the osmotic potential of $-0.3 \mathrm{MPa}$ (Table 2). Despite the germination in $\mathrm{NaCl}$ and $\mathrm{CaCl}_{2}$ salts at the potential of $-0.3 \mathrm{MPa}$, this was significantly lower than that in the control and in the $\mathrm{NaCl}$ solution. According to Ferreira et al. (2017), the effects of $\mathrm{NaCl}$ are more pronounced due to the toxicity of the sodium in its chemical composition. Similar to the fava bean seeds in $\mathrm{MgCl}_{2}$ solution $(-0.3 \mathrm{MPa})$, maize germination did not differ significantly from the control (Table 2).

Table 2. Germination percentage (G\%), germination speed index (GSI), and average germination time (AGT) of creole corn seeds as a function of different salts and osmotic potentials.

\begin{tabular}{|c|c|c|c|c|c|c|c|c|c|c|}
\hline \multirow{2}{*}{ Variable } & \multirow{2}{*}{ Control } & \multicolumn{9}{|c|}{ Salts } \\
\hline & & $\begin{array}{c}\mathrm{NaCl} \\
-0.3\end{array}$ & $\begin{array}{c}\mathrm{NaCl} \\
-0.9\end{array}$ & $\begin{array}{c}\mathrm{NaCl} \\
-1.2\end{array}$ & $\begin{array}{c}\mathrm{CaCl}_{2} \\
-0.3\end{array}$ & $\begin{array}{c}\mathrm{CaCl}_{2} \\
-0.9\end{array}$ & $\begin{array}{c}\mathrm{CaCl}_{2} \\
-1.2\end{array}$ & $\begin{array}{c}\mathrm{MgCl}_{2} \\
-0.3\end{array}$ & $\begin{array}{c}\mathrm{MgCl}_{2} \\
-0.9\end{array}$ & $\begin{array}{c}\mathrm{MgCl}_{2} \\
-1.2\end{array}$ \\
\hline G (\%) & 81.1 & $18.9^{*}$ & $0.0^{*}$ & $0.0^{*}$ & $27.8^{*}$ & $0.0^{*}$ & $0.0^{*}$ & $70.0^{\mathrm{ns}}$ & $31.1^{*}$ & $27.8^{*}$ \\
\hline GSI & 1.5 & $0.3^{*}$ & $0.0^{*}$ & $0.0^{*}$ & $0.5^{*}$ & $0.0^{*}$ & $0.0^{*}$ & $1.2^{*}$ & $0.5^{*}$ & $0.5^{*}$ \\
\hline AGT & 5.7 & $5.4^{\mathrm{ns}}$ & $0.0^{*}$ & $0.0^{*}$ & $6.6^{\mathrm{ns}}$ & $0.0^{*}$ & $0.0^{*}$ & $7.3^{\mathrm{ns}}$ & $7.8^{*}$ & $5.6^{\mathrm{ns}}$ \\
\hline
\end{tabular}

$* \mathrm{P}<0.05 ;{ }^{\mathrm{ns}} \mathrm{P}>0.05$

The germination percentage decreased as the concentrations of the $\mathrm{NaCl}$ and $\mathrm{CaCl}_{2}$ salts was increased, the values were zero for both maize and fava bean seeds after $-0.9 \mathrm{MPa}$ (Tables 1 and 2). Increases in salt content in the substrate decrease the water potential (REBOUÇAS, et al., 1989), which interfere with the water absorption kinetics and facilitates the entry of toxic ions (BRACCINI et al., 1996), which directly affects germination and plant development.

The $\mathrm{MgCl}_{2}$ salt solution was, in general, the least harmful to the fava bean and maize seed germination, the germination percentage under potential of $-0.3 \mathrm{MPa}$ was similar to that of the control for both species. The germination in the -0.9 MPa potential was $31.1 \%$ for maize and $6 \%$ for fava bean seeds, and under the osmotic potential of -1.2 $\mathrm{MPa}$, it was $27.8 \%$ for maize seeds.

Germination is higher in salt-free or low-salt environments, and there are few halophytes that can germinate under osmotic potential between -1 and -2 $\mathrm{MPa}$. Usually, the osmotic potential upper limit for germination and seedling growth is approximately -0.5 to $-0.7 \mathrm{MPa}$, or less (LARCHER, 2000).

Considering that a high GSI infer a that the seed lot is very vigorous (FERREIRA; BORGHETTI, 2004), the salts at germination decreased the seed vigor, resulting in a GSI significantly lower than that of the control for all salt solutions and for both creole fava bean (Table 1) and maize seeds (Table 2). Similar results were found by Araújo et al. (2018) when evaluating Phaseolus vulgaris L. seeds, who reported decreases in GSI as the salt concentration was increased. According to Martins, Pereira, and Lopes (2014), increasing environmental stress decrease germination speed.

Longer germination times were found with $\mathrm{MgCl}_{2}$ salt at $-0.3 \mathrm{MPa}$ for the fava bean seeds (Table 1), and with $\mathrm{MgCl}_{2}$ at -0.3 and $-0.9 \mathrm{MPa}$ for the maize seeds; $\mathrm{CaCl}_{2}$ at $-0.3 \mathrm{MPa}$ also showed similar results (Table 2). These results negatively affected the establishment of the species, since increases in average germination time can change the uniformity of production (QUEIROZ et al., 2016).

Since seeds subjected to lower osmotic potentials had slower germination, their use in areas with high-salinity soils or soils irrigated with salt water is not recommended. Contrastingly, Conus et al. (2009) reported that maize seed germination is not affected by salt stress; however, decreases in osmotic potential by $\mathrm{KCl}$ and $\mathrm{NaCl}$ solutions cause decreases in shoot length and increases in primary root length.

The relative germination frequency (RGF) shows the germination distribution over time. The highest GRF of maize seeds was found between the 0 and $8^{\text {th }}$ day for most treatments (Figure 1). This was due to the correlation of this variable with germination percentage; the germination for these treatments occurred mainly in the first days. 


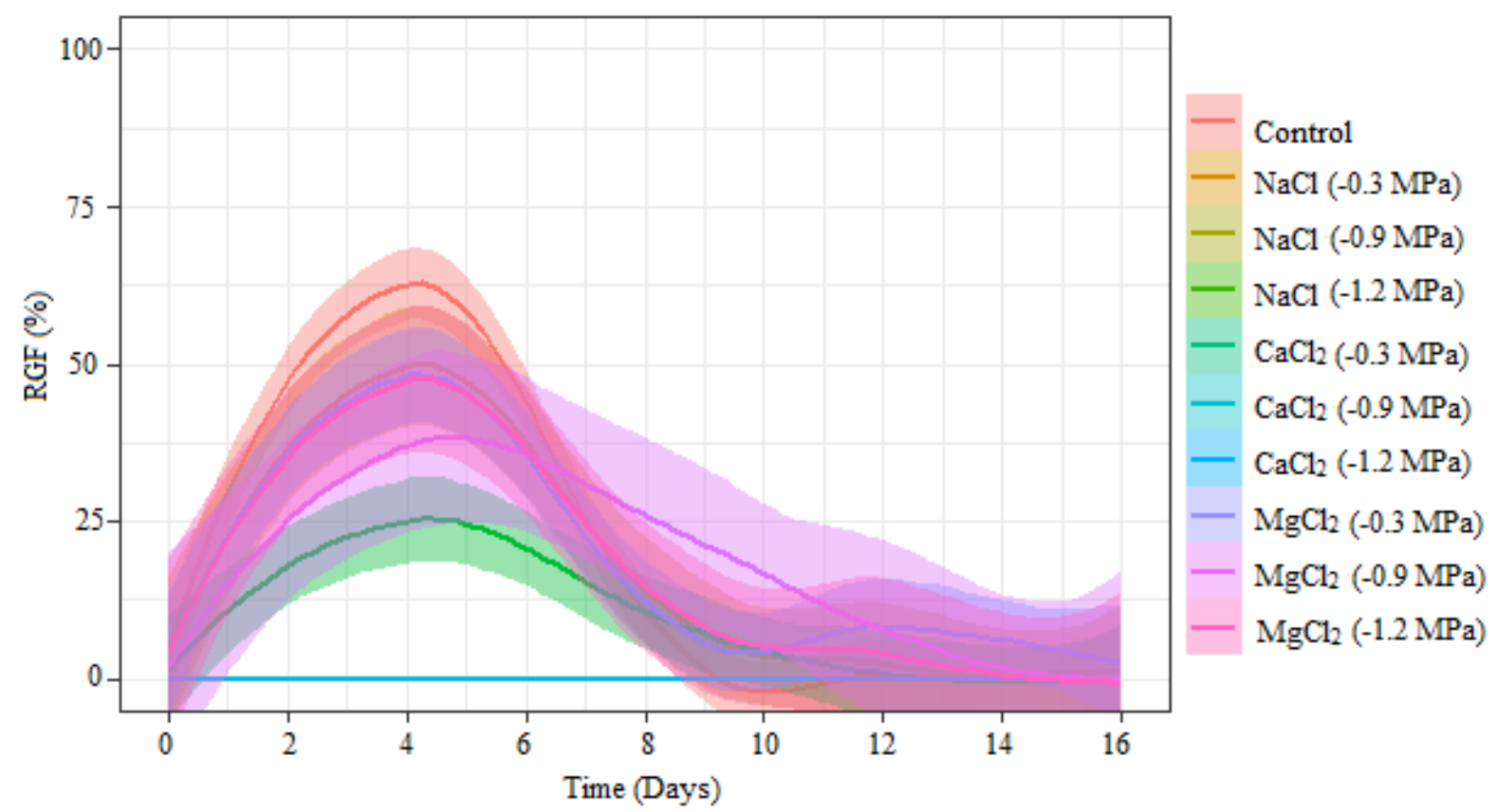

Figure 1. Relative germination frequency of corn creole seeds as a function of different salts and osmotic potentials.

The $\mathrm{CaCl}_{2}(-1.2 \mathrm{MPa})$ treatment differed significantly from the others between the 0 and $8^{\text {th }}$ day, which is explained by the lack of maize seed germination in this salt concentration. The RFG of the treatments was similar from the $10^{\text {th }}$ to the $16^{\text {th }}$ day, varying between 0 and $25 \%$ (Figure 1). According to Oliveira et al. (2011), the faster the germination process, the lower the chance of seed contamination with pathogens.
Fava bean seeds presented germination only in the treatments control, $\mathrm{MgCl}_{2}-0.3$ and $\mathrm{MgCl}_{2}-0.9$ $\mathrm{MPa}$, with the highest RGF in the control from the $5^{\text {th }}$ to the $8^{\text {th }}$ day, which was significantly higher than those in the other treatments (Figure 2). The greatest RGF from the $10^{\text {th }}$ to the $16^{\text {th }}$ day was found for the treatment $\mathrm{MgCl}_{2}-0.3 \mathrm{MPa}$.

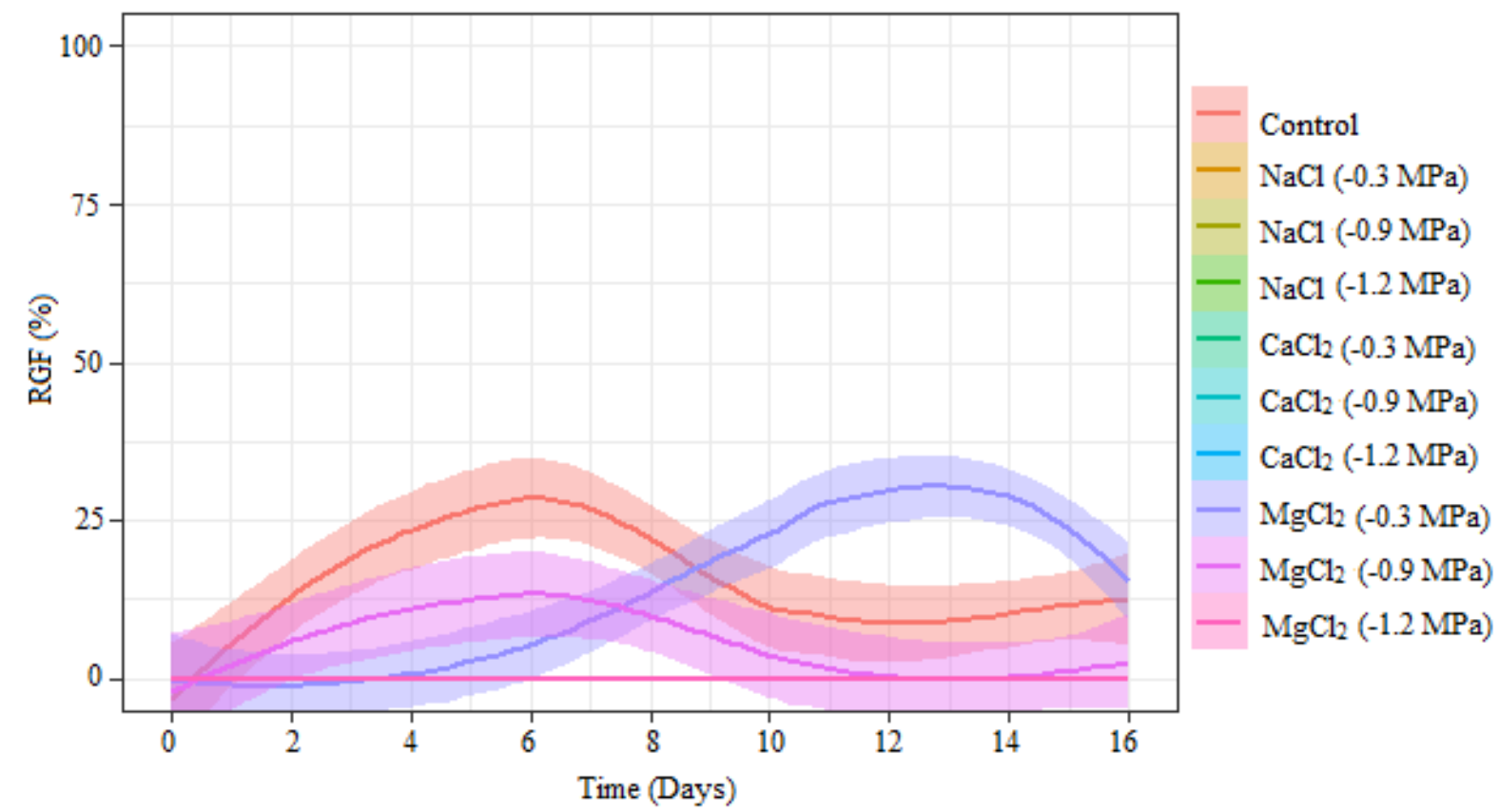

Figure 2. Relative germination frequency of fava beans creole seeds as a function of different salts and osmotic potentials. 
Although creole maize and fava bean seeds had the same germination capacity as the control when subjected to the $\mathrm{MgCl}_{2}$ salt solution with the osmotic potential of $-0.3 \mathrm{MPa}$, the highest FGR was found in the first days for maize, and from the $8^{\text {th }}$ day for fava bean. Thus, although they have germinated under salt stress conditions, these seeds may have had their vigor compromised, and considering that their germination time increase, their crop cycle may have changed. According to Silva et al. (2014), studies on adaptation to environmental stress are very useful and allow the selection of crops and genotypes that are more tolerant and capable of producing well, even under in environments with excess salts.

\section{CONCLUSIONS}

The storage of creole maize and fava bean seeds in plastic bottles and under adequate humidity ensures that seeds will have moisture content and physical purity within ideal values. Salt stresses induced by $\mathrm{NaCl}$, and $\mathrm{CaCl}_{2}$ salts at osmotic potentials of -0.3 to $-1.2 \mathrm{MPa}$ hinder the creole maize and fava bean seed germination, and their germination are null for both salts at osmotic potentials lower than $-0.3 \mathrm{MPa}$. The creole maize and fava bean seeds show germination of $70 \%$ under salt stress induced by $\mathrm{MgCl}_{2}$ at osmotic potential of $0.3 \mathrm{MPa}$, making the germination of both species viable.

\section{REFERENCES}

ARAÚJO, M. L. et al. Efeito de diferentes potenciais osmóticos sobre a germinação e o desenvolvimento de plântulas de feijão enxofre. Ensaios e Ciência: Ciências Biológicas, Agrárias e da Saúde, 22: 201204, 2018.

BARAVIERA, C. M. C. et al. Avaliação de propriedades físicas de grãos de híbridos de milho. Enciclopédia Biosfera, Centro Científico Conhecer, 10: 291-297, 2014.

BARREIRO NETO, M. et al. Características morfológicas e produtivas em acessos de feijão-fava consorciados. Tecnologia \& Ciência Agropecuária, 9: 23-27, 2015.

BRACCINI, A. L. et al. Germinação e vigor de sementes de soja sob estresse hídrico induzido por soluções de cloreto de sódio, manitol e polietilenoglicol. Revista Brasileira de Sementes, 18: 10-16, 1996.
BRASIL. Ministério da Agricultura, Pecuária e Abastecimento. Regras para análise de sementes. Ministério da Agricultura, Pecuária e Abastecimento. Secretaria de Defesa Agropecuária. Brasília, DF: Mapa/ ACS, 2009. 395 p.

CLEVELAND, W. S.; DEVLIN, S. J. Locally Weighted Regression: An Approach to Regression Analysis by Local Fitting. Journal of the American Statistical Association, 83: 596-610, 1988.

COELHO, D. L. M. et al. Estresse hídrico com diferentes osmóticos em sementes de feijão e expressão diferencial de proteínas durante a germinação. Acta Scientiarum. Agronomy, 32: 491 $-499,2010$.

CONUS, L. A. et al. Germinação de sementes e vigor de plântulas de milho submetidas ao estresse salino induzido por diferentes sais. Revista Brasileira de Sementes, 31: 67-74, 2009.

FERREIRA, A. G.; BORGUETTI, F. Germinação do básico ao aplicado. Porto Alegre, RS: Artmed, 2004, 323 p.

FERREIRA, A. C. T. et al. Water and salt stresses on germination of cowpea (Vigna unguiculata cv. BRS Tumucumaque) seeds. Revista Caatinga, 30: 10091016, 2017.

FERREIRA, R. L.; SÁ, M. E. Contribuição de etapas do beneficiamento na qualidade fisiológica de sementes de dois híbridos de milho. Revista Brasileira de Sementes, 32: 99-110, 2010.

GUIMARÃES, S. F. et al. Influência de substratos na germinação de sementes de Camomila (Matricaria recutita). Horticultura Brasileira, 30: 5226-5233, 2012.

GOMES FILHO, A. et al. Estresse hídrico e salino na germinação de sementes de feijão-caupi cv. BRS Pajeú. Colloquium Agrariae, 15: 60-73, 2019.

HOLANDA, A. C. et al. Desenvolvimento inicial de espécies arbóreas em ambientes degradados por sais. Revista de Biologia e Ciências da Terra, 7: 39-50, 2007.

LABOURIAU, L. G.; VALADARES, M. E. B. On the germination of seeds Calotropis procera (Ait.) Ait.f. Anais da Academia Brasileira de Ciências, 48: 263-284, 1976.

LARCHER, W. Ecofisiologia vegetal. São Carlos, SP: RIMA, 2000, 531 p. 
MAGUIRE, J. D. Speed of germination-aid selection and evaluation for seedling emergence and vigor. Crop Science, 2: 176-177, 1962.

MARTINS, C. C.; PEREIRA, M. R. R.; LOPES, M. T. G. Germinação de sementes de eucalipto sob estresse hídrico e salino. Bioscience Journal, 30: 318-329, 2014.

MORAIS, M. A. S. et al. O NaCl inibe a germinação e a atividade da amilase em duas espécies de feijão. Revista Nordestina de Ciências Biológicas, 1: 5056,2018 .

NASCIMENTO, M. G. R. et al. Lima bean (Phaseolus lunatus L.) seeds exposed to different salt concentrations and temperatures. Revista Caatinga, 30: 738-747, 2017.

NUNES, L. R. L, et al. Germinação e vigor de sementes de feijão-caupi em resposta aos estresses salino e térmico. Revista Caatinga, 32: 143-151, 2019.

OLIVEIRA, A. K. M. et al. Germinação de sementes de Aspidosperma tomentosum Mart. (Apocynaceae) em diferentes temperaturas. Brazilian Journal of Biological Sciences, 9: 392-397, 2011.

PESSOA NETO, J. A. et al. Qualidade fisiológica de sementes de milho sob condições de estresse salino. Cultura Agronômica, 25: 401-408, 2016.

QUEIROZ, R. L. et al. Avaliação de extrato de Melaleuca alternifolia (Cheel) na germinação de Brachiaria brizantha. Revista Fitos, 10: 375-547, 2016.

R CORE TEAM. R: The R project for statistical computing; 2016. Disponivel em: <https://www.rproject.org > . Acesso em: 11 jun. 2019.

REBOUÇAS, M. A. et al. Crescimento e conteúdo de $\mathrm{N}, \mathrm{P}, \mathrm{K}$ e $\mathrm{Na}$ em três cultivares de algodão sob condições de estresse salino. Revista Brasileira de Fisiologia Vegetal, 1: 79-85, 1989.

SANTOS, A. D; CURADO, F. F; TAVARES, E. D. Pesquisas com sementes crioulas e suas interações com as políticas públicas na região Nordeste do Brasil. Cadernos de Ciência \& Tecnologia, 36: 119, 2019.

SANTOS, M. S. et al. Sementes crioulas: Sustentabilidade no semiárido paraibano. Revista Agrarian Academy, Centro Científico Conhecer, 4: 1-16, 2017.
SARMENTO, H. G; DAVID, A, M. S. S; BARBOSA, M. G. Determinação do Teor de Água em Sementes de Milho, Feijão e Pinhão - Manso por Métodos Alternativos. Energia na Agricultura, 30: 249-256, 2015

SILVA, L. D. A, et al. Mecanismos fisiológicos em híbridos de citros sob estresse salino em cultivo hidropônico. Revista Brasileira de Engenharia Agrícola e Ambiental, 18: 1-7, 2014.

SILVA, R. C; CRZYBOWKI, C. R. S; PANOBIANCO, M. Vigor de sementes de milho: influência no desenvolvimento de plântulas em condições de estresse salino. Revista Ciência Agronômica, 47: 491- 499, 2016. 